NINA ZAICEVA

Karelian Research Centre of

the Russian Academy of Sciences

\title{
Veps language heritage in Karelia ${ }^{1}$
}

\section{Introduction}

Veps people live in Russia on the border of the Republic of Karelia, in Leningrad region and Vologda region. Based on the most recent Russian population census in 2010 (Vserossijskaja perepis naselenija 2010), 5936 people consider themselves Veps, of which 3423 live in Karelia, 1380 live in Leningrad region, and 412 live in Vologda region. The decline in the Veps population and Veps language skills has been an urgent matter for researchers, society, and state authorities. In 2000, a Russian Federation government decree listed the Veps people in the Russian Federation Joint List of Indigenous Minorities as a community under special state protection (see Strogalschikova 2014: 237, 245). The Veps language also was included in the Russian Federation Red List of Languages (Krasnaja kniga 1994: 21-22). These efforts were intended to stimulate Veps language revitalization and cultural preservation as well as restoring active bilingualism in areas where Veps language teaching in schools would be helpful. In the Republic of Karelia, several books in Veps have been published: textbooks for schools and universities, phrase books, bilingual dictionaries, and spelling dictionaries (see Zaiceva 2006: 119-135). The Veps media consist of the newspaper Kodima, the magazine Kipinä for children (in Veps, Kibin), and weekly TV and radio programs.

1. The study was carried out under state order (Project No. AAAA-A18118012490344-5). 
Publishing in Veps was possible due to the gathering of Veps language material and language research. Special mention should be made of the valuable Veps dialect dictionary by Maria Zaiceva and Maria Mullonen (1972), which is one of the best works by Russian linguists in the field of Veps language research. The knowledge and insight provided by the dictionary into Veps grammar and its lexicon allowed for the development of richer materials for language revitalization representative of the way contemporary Veps is used by its speakers.

The first expeditions to collect linguistic and ethnographic material in Veps villages were made quite late. Finnish researchers were the first to visit Veps villages in the second half of the $19^{\text {th }}$ century during the period characterized by the Neogrammarian movement. As a result of these first expeditions by Finnish researchers, linguists today have dialect samples from the end of the $19^{\text {th }}$ century and from the beginning of the $20^{\text {th }}$ century. This fact is extremely important for a nation that does not have old written records.

A wider interest in the Veps language and its cultural heritage developed at the beginning of the $20^{\text {th }}$ century. The most effective work on Veps language research was carried out in Karelia at the Institute of History, Literature, and Language at the Karelian Research Centre of the Russian Academy of Sciences (RAS). Following expeditions to Veps-speaking regions during the beginning of the second half of the $20^{\text {th }}$ century, researchers began using these language data in their own studies, and the language was presented on the maps of an atlas, Atlas Linguarum Europae (1975-2007). The archives of the Institute have a significant amount of Veps language material. These materials include dialect recordings on magnetic tapes, written dialect samples, manuscripts, and material in the modern Standard Veps language published in books, newspapers, magazines, and electronically. 


\section{Veps recordings in the phonogram \\ archive of the Institute of History, \\ Literature, and Language at the \\ Karelian Research Centre of the RAS}

The phonogram archive of the Institute of History, Literature, and Language at the Karelian Research Centre of the RAS has significant recorded material in Veps dialects, which also includes information about the culture and the history of the Veps nation. The phonogram archive has over 400 hours of Veps tape recordings. Currently, this is one of the richest and most unique collections of Veps dialect samples. The dialogue and monologue texts in this collection are on different topics relating to Veps ethnography, culture, daily life, and folklore. A small part of this material has been transcribed and used in research.

The Karelian Research Centre of the RAS first began carrying out expeditions to the Veps villages in the beginning of the 1950s when language researchers, ethnographers, and folklore researchers started to conduct many expeditions to the Veps-speaking areas. Expeditions were also carried out to areas with place names indicating that Veps had once been spoken there. The recordings from these expeditions are preserved in the phonogram archive of the Institute.

The Veps material in the phonogram archive was digitized and has an electronic registration, which identifies the tape number, the year and place of recording, the consultant, the researcher, the topic of conversation, and the genre of the recording. Using this electronic registration, the author of this report was able to make a map of the expedition destinations (Map 1) and to compile a table listing the expeditions (see Appendix 1 at the end of this report).

The researchers indicated the local center when making their lists; however, each center includes many small localities. For example, the place name Voilahta (Veps Voilaht) covers three villages: Markovo (Markutan), Virino (Virahtan), and Pustoshka (Pust). Therefore, the number of localities visited during the expeditions greatly exceeds the number of place names in Appendix 1. The researchers often made many trips to the same regions conducting 130 expeditions in total.

The dialect material is represented heterogeneously: the largest portion of the material was recorded in central localities, while less 



\section{Northern Veps dialect}

Him $=$ Himdeg, $K l=$ Kaleig, Kas $=$ Kaskezoja, Ms = Matvejan Sel'g, Mec = Mecantaga, Mäg = Mägi, Oger $=$ Ogerišt, Tž $=$ Toižeg, $\check{S}=\check{S}$ okš, $\check{S} t=\check{S}$ outarv, Veh $=$ Vehkoja .

\section{Middle Veps dialect Eastern subdialects}

$K j=K u j a, \check{S} u s ̌ t=$ Ošt, Pnd $=$ Pondal, $P k=$ Püutkask, Päž $=$ Päžar', Sär $=$

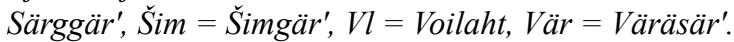

\section{Middle Veps dialect Western subdialects}

Har $=$ Haragl, $\check{C i k}=\check{C}$ ikl, Jä $=$ Järved, Kar $=$ Karhil, Kor $=$ Korbal, Korv $=$ Korval, Kkz $=$ Kukkaz, Kurb $=$ Kurb, Ladv $=$ Ladv, Mg = Mäggär', Nem = Nemž, Nir $=$ Nirgl, Noid $=$ Noidal, Nor $=$ Norj, Nür $=$ Nürgl, Pec $=$ Pecoil, Peč $=$ Pečl', Reb $=$ Rebag', Šon $=$ Šondjal, Vil $=$ Vil'häl .

\section{Southern Veps dialect}

Ars $=$ Arskaht', Bm = Bölämägi, Bor $=$ Bor, Čid $=\check{C}$ idoi, $F m=$ Fedramägi, Krl $=$ Kortlaht, Mai = Maigär, Lah = Laht, Mm = Maksimägi, Pož = Požarišš, Sod = Sodjärv, Šid = Šidjärv, Tim = Timoo, Vg = Vaagedjärv.

material was recorded in peripheral areas. For example, many recordings were made in Pondala (Veps Pondal; Vologda region, Babayevo district). This choice can be easily explained: this dialect is the base for the Veps dialect dictionary (M. Zaiceva \& M. Mullonen 1972). A large amount of material also was recorded in Ladva ( $L a d v)$ and Ozyora (Järved) in Leningrad region, Podporozhye district; in Sheltorezo (Šoutarv) in the Republic of Karelia; and in Radogotchshi (Arskaht'), Bobrozero (Maigär), and Beloye ozero (Vaagedjärv) in Leningrad region, Boktogorsk district. The phonogram archive has unique material recorded in Veps localities, which are no longer inhabited. This is the case for the villages of former Shimozero rural council (Šimgär'; Vologda region, Vytegra district), which was rehoused in the $1960 \mathrm{~s}^{2}$.

The materials include, for example, recordings of Veps from Kukkas village (Kukkaz, tape 102; recorded in Shapsha ( ̌́ap̌́), Leningrad region, Lopeynopolsky district) made by one of the first Veps language researchers, M. M. Hämäläinen. Kukkas village is described by E. A. Tunkelo as completely Russified in his 1946 monograph (Tunkelo 1946: 5). M. M. Hämäläinen, however, was able to find consultants and record their speech in 1959. The recordings are extremely

2. E. A. Tunkelo (1946: 6) mentioned Shimozero village with a population of 4936 of which $100 \%$ spoke the Veps language in the 1930s. 
interesting phonetically, due to the emergence of long vowels and exceptional short vowels.

The Kukkas subdialect features long vowels, apart from the other Veps dialects. In addition, rising diphthongs are represented in an unusual way, for example $l \boldsymbol{u} d a$ 'to make a basic fabric; to stack' (compare the usual Veps loda), lüda 'hit' (comp. löda), mühä 'late' (comp. möha), etc. These phonetic facts have not been mentioned in the past. Few examples from the materials of the archive show these phenomena (transliterated by the author of the report):

— Ka sä pagižed lüdikš? 'Do you speak Veps?'

- Ka maltan! 'Yes, I do!'

- Sanu minei erasid sanoid. Kut om 'položit' ceno v zarod (stog)'? 'Say some words. How to say: 'to put the hay to a stack'?'

- Luda hein sabrha.

- Kut sanutas - 'derevo', 'sest'?' 'How to say 'tree', 'six'?'

- Pии, kuиz'.

Mina paginan kuul'en 'I hear some speech'

Luи 'bone'

Pidäb juda 'One has to drink'

Pidäb tuda leibad 'One has to bring some bread'

Lüda 'hit', süda 'eat', mü da 'sell'

Hän tuli kodihe mühä 'He came home late'

Another example from the materials, a text recorded in 1960 by M. M. Hämäläinen from Grigoriy Bolshakov, born in 1914 (Voylakhta (Voilaht) village, Vologda region, Babayevo district, record 103), shows how the southern Veps designate themselves:

Triccatijiš voziš miiden derüuniš organizęihes kolhozat. Kuumo kolhozat oli. Markutanas kolhos kucịhe Krasnịi Čuhar'. Silęi mö em tunnuhu nečida vajeht 'veps'. A meit' kucuiba čuharikš. I kolhos-ki mugịine oli Čuhar', Krasni vüu. Virahtanas oli kolhos Krasnịi Partizan, Pustou Trinaccataja Godovššina. Kujahasai tägoupei kus' virstat, sigou mugažo kolhozat oliba: oli Krasni pahar', Bol'ševik, Krasnoarmejec oli. Pondlou-ki kolhozat organizęihe. No sigou oli üks' kolhos miiden kartho nazivajihe: nece kolhos Us' Elo. 
'There were collective farms in our villages in the 1930s. We had 3 collective farms. The collective farm in Markovo (Markutan) was called Krasny Chukhar. We did not know the word Veps. We were called Chukhars. The collective farm's name was Chukhar, even Krasny ('Red') Chukhar. The collective farm in Virino ( $\mathrm{Vi}$ rahtan) was called Krasny Partizan ('Red partisan'), the farm in Pustoshka (Pust) was called Trinadtsataya Godovshchina ('The $13^{\text {th }}$ century'). Kuya (Kuja) village is 6 versts from here, there were several collective farms: Krasny Pakhar ('Red plowman'), Bolshevik, Krasnoarmeyets ('Red Army soldier'). There were collective farms near Pondala (Pondal). But one collective farm was called in Veps: Us' Elo ('New life').'

The self-designation of Veps people speaking different Veps dialects is different. As seen in the example, the southern Veps call themselves bepslaažed or čuharid, whereas the northern Veps call themselves $l \ddot{u}$ dinikad and the Veps of Vologda region call themselves ičemoi rahvaz '(our) own nation'. Verbs about speaking are also different from each other: the southern Veps could say pagišta počudski 'to speak in a Chud way', the northern Veps say pagišta lidikš 'to speak Veps', and the Vologda Veps say pagišta ičemoi kartte 'to speak in (our) own way'.

\section{Veps materials in the manuscripts archive of the Institute of History, Literature, and Language at the Karelian Research Centre of the RAS}

The Karelian Research Centre has a manuscript archive, as well. The dialect collection, which consists of some transcribed manuscripts from the collection of Veps narratives, Obrazcy vepsskoj reči (M. Zaiceva \& M. Mullonen 1969), is not very large. The card index of the Veps dialect dictionary published in 1972 by Maria Zaiceva and Maria Mullonen is located in the archive of the Linguistics Section at the Institute. The card index contains handwritten cards in alphabetical order with Veps words presented along with their meaning and their use in the dialects together with examples. 
The Veps materials in the manuscript archive mostly consist of various types of questionnaires. These include the questionnaires used in compiling the Comparative Onomasiological Dictionary of the Karelian, Veps, and Saami languages, Sopostavitelno-onomasiologičeskij slovar' (2007), which was prepared by the linguists of the Institute. The questionnaire included 1500 lexical questions. The dialect material used for the dictionary was recorded in the field at the end of the 1980s and it presents the state of the dialects at that time. For the Veps material, the dictionary questionnaires were filled out in 6 Veps villages: Northern Veps from Sheltozero (Šoutarv) and Kaskesruchey (Kaskezoja); Middle Veps from Oshta (Ošt; includes material from Shimozero (Šimgär') as well), Voylakhta (Voilaht), and Ozyora (Järved); and Southern Veps from Sidorovo (Sodjärv).

The dictionary in general is a linguistic-geographic handbook of the aforementioned languages; its materials show lexical similarities and differences among languages and dialects. In compiling the dictionary, a conceptual-thematic method was used along with the conceptual register of Russian so that use of the large amount of material it contained would be easy for dialect research (of the Finnic and Saami languages presented in the dictionary).

The sociological questionnaires include a considerable amount of Veps material. The material collected by ethnosociologist Zinaida Strogalschikova between 1981-1983 forms a significant part of the archive. Two population censuses of the Soviet Union in 1970 and 1979 showed an almost complete disappearance of Veps people from their traditionally inhabited locations in Leningrad and Vologda regions. Many of the expeditions led by Zinaida Strogalschikova ${ }^{3}$ had the goal of providing an alternative census of the Veps population. This material was drawn from the data contained in the rural household registers of the villages inhabited by Veps people. These registers included basic information about the inhabitants: gender, age, place and time of birth, relation to the householder, marital status, place of work, employment, education, nationality, and duration of residency in a particular village. Information on the population of four of Leningrad region's districts (Podporozhye, Lodeynopolsky, Boksitogorsk, Tikhvin) and of

3. The author of the report also participated in these expeditions. 
Babayevo district of Vologda region was collected during the expeditions. It was determined that in 1981 there were 4087 Veps in villages in Leningrad region (318 according to the 1979 census) and 773 in Vologda region (41 according to the 1979 census). This meant that the 1979 census did not count approximately 4500 Veps. Information on inhabitants was collected in 81 larger and smaller villages. Material was also collected in Prionezhye district in the Republic of Karelia (see Strogalschikova 1989: 27-42 for more details).

The material gathered in 1981 became the basis for ethnosociological research carried out in 1983. Gender, age, education, and nationality were taken into consideration when deciding on a representative sample of interviewees. 400 Veps from Prionezhye district in Karelia and 400 Veps from Leningrad and Vologda regions were interviewed. The 1983 expedition lasted from June to December and interviews were conducted in all villages except the smallest ones.

The interviews were based on a questionnaire created by Zinaida Strogalschikova who used the questionnaires of V. V. Pimenov, L. S. Khristolyubova, and G. N. Belorukova as a base. Some questions were borrowed from the 1979 survey papers of the Karelian sociologists Y. I. Klementyev and A. A. Kozhanov. The questionnaire consisted of 118 questions and it included some open questions, for example, on opinions regarding the need for a Veps written language, the necessity of Veps language study in schools, and reasons for linguistic and ethnic assimilation. As one of the outcomes of the interviews, $92 \%$ of those interviewed in the Leningrad and Vologda regions confirmed their nationality as Veps, $6 \%$ called themselves Russians (half of these respondents had one Russian parent), and $2 \%$ were not able to choose between Veps and Russian as their nationality. The 1989 census showed that there were 4500 more Veps in the Leningrad and Vologda regions. Also, tape recordings of significant folklore material were made in the expeditions and transferred to the phonogram archive of the Institute of History, Literature, and Language at the Karelian Research Centre of the RAS.

The research material of the archives of the Institute of History, Literature, and Language served as a foundation for further research. This material was important in the revitalization of Veps at the end of the 1980 s. 


\section{Veps dialect samples published}

There are a few dialect samples published in Russia. Compared to the samples published in Finland, these include newer texts, as the expeditions and language research resulting in these samples was conducted more recently.

The collection of Veps narratives, Obrazcy vepsskoj reči, published by Maria Zaiceva and Maria Mullonen (1969), includes Middle and Southern Veps texts, but no Northern Veps texts, which is a gap in Russian science. This collection was published as a result of work on the Veps dialect dictionary.

Middle Veps texts recorded in Ladva $(L a d v)$ village in Podporozhye district of Leningrad region, transcribed by Maria Mullonen, were published in the collection Jazyk i narod (Irma Mullonen 2002). These texts include conversations on ethnographic topics with village inhabitants of various ages.

Veps folk tales can be found in the collection Vepsän rahvhan sarnad by Nina Onegina and Maria Zaiceva (1996). This collection utilizes the recordings of the Institute's phonogram archive and it includes texts from Prionezhye district in the Republic of Karelia as well as from the Leningrad and Vologda regions. In other words, it covers all Veps dialects: the Northern Veps of Šoutarv, Mecantaga, Šokš, $\mathrm{Ka}$ leig, Matvejansel'g, Tihoništ; the Middle Veps of Ladv, Järved, Pecoil, Pondal, Kuja; and the Southern Veps of Šidjärv and Sodjärv.

The collection Käte-ške käbedaks kägoihudeks, edited by Nina Zaiceva and Olga Zhukova (2012), introduces the largely unknown folklore genre of Veps lamentation. The editors transcribed material on almost all lamentation types (wedding, funeral, occasional lamentations) from the phonogram archive of the Institute of History, Literature, and Language. The book includes detailed information on the texts, consultants as well as the place and time of each recording. The number of localities providing the recorded material for this book is large: 19 Veps districts (see the list of localities in Zaiceva \& Zhukova (eds) 2012: 207-208). This large number of localities makes possible examination of dialect characteristics. In addition, the book includes musical notation from S. V. Kosyreva of the Petrozavodsk Conservatory for 25 lamentation songs. This genre of Veps folklore is presented for the first time with this amount of material. 
5. Veps dialect dictionary and atlases

A great deal of material can be found in the Veps dialect dictionary and atlases. The Veps dialect dictionary, Slovar' vepsskogo jazyka (M. Zaiceva \& M. Mullonen 1972), includes materials from almost all Veps localities. The authors made multiple expeditions to almost all locations within the Veps-speaking area. There they recorded a significant amount of material on Veps spiritual and material culture as well as Veps folklore. Recordings made by the authors are presented along with rich information on the consultants. Aleksandra Kalinina, a consultant with an excellent knowledge of Veps language and folklife culture, was discovered by the authors in Pondala (Babayevo district, Vologda region). For this reason, this dialect was used as the base dialect for the Veps dialect dictionary. The lexis of 31 localities (18 Middle Veps, 7 Southern Veps, and 6 Northern Veps) was used in the dictionary. The dictionary includes subdialects of the Middle Veps dialect from the villages of Čikl, Enar'v, Järved, Karhil, Korbal, Kuja, Ladv, Nirgl, Noidal, Pecoil, Pondal, Püutkask, Päžar', Šimgär', Särggär', Vil'häl, Voilaht, and Väräsär'; of the Southern Veps dialect from Arskaht', Čaigl, Kortlaht, Maigär', Sodjärv, Šidjärv, and Vaagedjärv; and the Northern Veps dialect from Kaleig, Kaskezoja, Mecantaga, Pervakat, Šokšs, and Šoutarv. A large proportion of the recordings was made in the remote and easternmost Veps villages of Pondal, Kuja, and Voilaht in Babayevo district of Vologda region. The dictionary also utilizes recordings from villages, which have ceased to exist since then: Šimgär', Väräsär', Särggär', and Kortlaht. Each word is presented together with its variants in other dialects. Veps was used as a written language in the 1930s and in the beginning of the 1990s when the Veps written tradition was revitalized. This dictionary served as a foundation for the Veps orthography and various dictionaries and textbooks.

Veps dialect material is also presented in linguistic-geographic studies. The first atlas that included Veps dialect material was the Atlas Linguarum Europae (ALE 1975-2007), which included Veps language material on separate maps. The material for the atlas was collected by Maria Zaiceva and Nina Zaiceva in six Veps localities (Šoutarv, Kaskezoja, Ošt, Voilaht, Järved, Sodjärv). The questionnaires 
completed in the 1980s are kept in the manuscript archive of the Institute of History, Literature, and Language at the Karelian Research Centre of the RAS.

Veps dialect material is described quite completely in the threevolume Atlas Linguarum Fennicarum (ALFE 2004-2010) prepared by an international group of authors from Finland, Estonia, and the Republic of Karelia in Russia. In preparing the atlas, the work of completing the questionnaires was done in seven Veps localities (Northern Veps: Šoutarv, Kaskezoja; Middle Veps: Järved, Voilaht, Šimgär'; Southern Veps: Sodjärv, Kortlaht). It should be noted that the material was collected in Kortlaht village by Nina Zaiceva and Irma Mullonen at the end of the 1980s from the last three inhabitants who left the village relatively soon after the expedition. This village is not inhabited anymore.

The Atlas of the Veps language (LAVJa) was published in 2019. The idea of a Veps atlas originates in the 1940s when work on the Karelian language atlas (Bubrih, Beljakov \& Punžina 1997), performed under the guidance of D. V. Bubrikh, a professor and a corresponding member of the USSR Academy of Sciences, was being carried out. The work on a linguistic atlas of the Veps language began in 2012 with the support of the Russian Foundation for Humanities under the guidance of project manager Nina Zaiceva. The dialect material was collected in 2012-2013 using a new questionnaire ${ }^{4}$ (see Voprosnik 2013) based on some of the ideas incorporated into the questionnaire from the 1940s. A large portion of the new questionnaire (266 questions of 395) consists of lexis questions. The material for the atlas was collected from 30 localities where good informants could be found. In addition, published and archival sources from a total of 75 localities were used, of which 17 are Northern Veps, 40 Middle Veps, and 18 Southern Veps. It is necessary for this work to be the largest ever on dialect material in order for it to expand on the topic of the dialects, to characterize the criteria for the formation of the Veps dialect regions, and to analyze, if possible, the formation and development of the dialects.

4. Nina Zaiceva, Irma Mullonen, researchers from Petrozavodsk, and Sergei Myznikov and I. V. Brodsky, researchers from Saint Petersburg, participated in the work on the new questionnaire. 


\section{Veps language corpus and material in the media}

Currently, dialect material and material written in the modern Veps language is available online as the Veps language corpus (Korpus vepsskogo $j a z y k a$ ), see (vepsian.krc.karelia.ru〉. The idea to make a Veps language corpus originated in 2010 . The goal of this project was a straightforward one: to make a corpus that includes a small amount of original oral and written texts and to put these online. A lemma is defined as a Veps written language word and is used as a reference for the dialect forms.

This electronic resource is open to all users. The texts are in five subcorpuses allowing one to become acquainted with dialect differences and with materials in the modern written language:

1) Dialect text subcorpus (parallel with translations in Russian)

2) Veps lamentation corpus (parallel with translations in Russian)

3) Veps folk tale corpus (parallel with translations in Russian)

4) Bible texts (modern written language texts)

5) Modern written language text corpus (texts from the newspaper Kodima, the magazine Kipinä, and other literary texts).

In addition to the the texts, the corpus also includes an electronic dictionary. Lexical elements are marked with their part of speech and have Russian and English translations. At the end of 2014, the corpus and the dictionary included over one thousand texts, about 800 bibliographic sources, and over 10000 lemmas and word forms.

The corpus includes various texts in the modern Veps written language created mostly due to the efforts of researchers from the Republic of Karelia. The texts from the newspaper Kodima, many of the texts from the Children's Bible and the New Testament, and the literary texts are written after 1992. These show changes in the written language, changes in its lexis, and the development of the rules of Veps grammar, stylistics, and spelling.

Periodika, the publisher of the newspaper Kodima, the children's magazine Kipinä, and the literary almanac Verez tullei, keeps all the text files in its archive. In addition, the publishing house places the material from the newspaper and magazine online, thereby enabling the wider public to have access to it. 
References

ALE = Atlas Linguarum Europae. 1975-2007. Assen: Van Gorcum \& Roma: Poligrafico.

ALFE = Atlas Linguarum Fennicarum 1-3. Itämerensuomalainen kielikartasto. Läänemeresoome keeleatlas. Ostseefinnischer Sprachatlas. Lingvističeskij atlas pribaltijsko-finskix jazykov. 2004-2010. Helsinki: Suomalaisen Kirjallisuuden Seura \& Kotimaisten kielten tutkimuskeskus. Available at: 〈https://avaa.tdata.fi/web/avaa/-/kotus-kielikartastot〉

Bubrih, D[mitri] V., A[leksandr] A. Beljakov \& A[leksandra] V. Punžina 1997: Dialektologičeskij atlas karel'skogo jazyka. Karjalan kielen murrekartasto. [Atlas of the Karelian language.] Ed. Leena Sarvas. Institut jazyka, literatury i istorii Karel'skogo naučnogo centra RAN \& Naučno-issledovatel'skij centr jazykov Finljandii. Kotimaisten kielten tutkimuskeskuksen julkaisuja 97. Helsinki: Société Finno-Ougrienne.

Kipinä. [Children's magazine.] Petroskoi: Periodika. 2011-. Available at: 〈http://kipina.rkperiodika.ru〉

Kodima. [Newspaper.] Petroskoi: Periodika. 1993-. Available at: «http://kodima. rkperiodika.ru>

Korpus vepsskogo jazyka [Veps language corpus]. Available at: 〈http://vepsian. krc.karelia.ru/text/>

Krasnaja kniga 1994 = Krasnaja kniga jazykov narodov Rossii. Ėnciklopedičeskij slovar'-spravočnik. [The Red Book of the languages of the peoples of Russia.] Ed. V. P. Neroznak. 1994. Moskva: Academia.

LAVJa = Lingvističeskij atlas vepsskogo jazyka [Atlas of the Veps language]. 2019. N[ina] G. Zaiceva (ed.). Sankt-Peterburg: Federalnyj issledovatel'skij centr. "Karel'skij naučnyj centr Rossijskoj akademii nauk". Institut jazyka, literatury i istorii \& Nestor-Istorija.

Mullonen, I[rma] I. 2002: Obrazcy reči žitelej sela Ladva Podporožskogo rajona Leningradskoj oblasti [Examples of the speech of the inhabitants of the village of Ladva in Podporože disrict in Leningrad region]. A. Gerd, M. Savijärvi \& T. de Graaf (eds), Jazyk $i$ narod. Teksty $i$ kommentarii razgovornoj reči pribaltijsko-finskix jazykov i dialektov russkogo jazyka na Severo-zapade Rossii. Sankt-Peterburg. 55-96.

Onegina, N[ina] F. \& M[aria] I. Zaiceva (eds) 1996: Vepsän rahvhan sarnad. Vepsskie narodnye skazki. [Veps folk tales.] Pamjatniki fol'klora Karelii. Petrozavodsk: Karelija.

Sopostavitelno-onomasiologičeskij slovar' = Sopostavitelno-onomasiologičeskij slovar' dialektov karel'skogo, vepsskogo, saamskogo jazykov [Comparative onomasiological dictionary of the Karelian, Veps, and Saami languages]. Ju. S. Eliseev, N. G. Zaiceva (eds). 2007. Petroza- 
vodsk: Rossijskaja akademija nauk. Karel'skij naučnyj centr. Institut jazyka, literatury i istorii.

Strogalschikova, Z[inaida] I. 1989: Ob ètnodemografičeskix tendencijax, social'no-èkonomičeskom i kul'turnom razvitii vepsskoj narodnosti [On the ethnodemographic tendencies, socioeconomic and cultural development of the Veps people]. V. V. Pimenov, Z. I. Strogalschikova \& Ju. Ju. Surxasko (eds), Problemy istorii i kul'tury vepsskoj narodnosti. Petrozavodsk: Karel'skij filial AN SSSR.

_ 2014: Vepsy. Očerki istorii i kul'tury. [The Veps. Essays on history and culture.] Sankt-Peterburg.

Tunkelo, E. A. 1946: Vepsän kielen äännehistoria [Sound history of the Veps language]. Suomalaisen Kirjallisuuden Seuran Toimituksia 228. Helsinki: Suomalaisen Kirjallisuuden Seura.

Verez tullei. [Annual literature almanac.] Petroskoi: Periodika.

Voprosnik 2013 = Voprosnik "Lingvističeskogo atlasa vepsskogo jazyka" [Questionnaire "Linguistic atlas of the Veps language"]. N. G. Zaiceva \& S. A. Myznikov (eds), Vepsskie areal'nye issledovanija. Petrozavodsk: Karel'skij naučnyj centr RAN. 7-45.

Vserossijskaja perepis naselenija 2010. Natsionalnyi sostav naselenija po subjektam Rossijskoi federatsii [The Russian census of 2010. Part 1. Population number and distribution. Table 7 [MS Excel table]]. Federalnaja služba gosudarstvennoi statistiki [Statistical office of the Russian Federation], 2012. Moscow: ИИЦ "Статистика России". [Accessed 15 Sept 2015] Available at: 〈http://www.gks.ru/free_doc/new_site/population/demo/per-itog/tab7.xls〉

Zaiceva, N[ina] G. 2006: Mladopis'mennyj jazyk vepsov: periody i perspektivy razvitija [Veps as a newly written language: periods and perspectives for development]. Sovremennaja nauka o vepsax: dostiženija i perspektivy (pamjati N. I. Bogdanova). Ed. I. Ju. Vinokurova. Petrozavodsk: Rossijskaja akademija nauk. Karel'skij naučnyj centr. 119-177.

Zaiceva, M[aria] I. \& M[aria] I. Mullonen 1969: Obrazcy vepsskoj reči [Samples of Veps dialects]. Akademija Nauk SSSR. Karel'skij filial. Leningrad: Nauka.

1972: Slovar' vepsskogo jazyka [Dictionary of the Veps language]. Akademija Nauk SSSR. Karel'skij filial. Institut jazyka, literatury i istorii. Leningrad: Nauka.

Zaiceva, N[ina] G. \& O[lga] Ju. Zhukova (eds) 2012: Käte-ške käbedaks kägoihudeks. 'Obernis'-ka miloj kukušečkoj'. Vepsskie pričitanija. [Turn into a sweet cuckoo. Veps lamentations.] Petrozavodsk: Juminkeko \& Karel'skij naučnyj centr. Rossijskaja akademija nauk. Institut jazyka, literatury i istorii. 
Appendix I. Expeditions to the Veps-speaking areas conducted by researchers from the Institute of History, Literature, and Language at the Karelian Research Centre of the RAS (1952-2012).

Northern Veps dialect

\begin{tabular}{|c|c|c|c|c|}
\hline $\begin{array}{l}\text { Place name in Veps } \\
\text { and abbreviation }\end{array}$ & $\begin{array}{l}\text { Place name in } \\
\text { Russian }\end{array}$ & $\begin{array}{l}\text { Region/district of } \\
\text { the place where the } \\
\text { recording was made }\end{array}$ & $\begin{array}{l}\text { Year } \\
\text { of the } \\
\text { recording }\end{array}$ & Researcher \\
\hline Himdeg (Him) & Гимрека & \begin{tabular}{|l} 
Leningrad \\
region, \\
Podporozhye \\
district \\
\end{tabular} & $\begin{array}{l}1962 \\
1983\end{array}$ & Vinokurova, I. Ju. \\
\hline Kaleig $(K l)$ & Рыбрека & \begin{tabular}{|l|} 
Republic \\
of Karelia, \\
Prionezhsky \\
district \\
\end{tabular} & $\begin{array}{l}1983 \\
1991\end{array}$ & $\begin{array}{l}\text { Strogalschikova, Z. I., } \\
\text { Vinokurova, I. Ju. }\end{array}$ \\
\hline $\begin{array}{l}\text { Kaskezoja } \\
\text { (Kas) }\end{array}$ & Каскесручей & $-\ll-$ & $\begin{array}{l}1970 \\
1983\end{array}$ & $\begin{array}{l}\text { Mullonen, I. I., } \\
\text { Zaiceva, N. G., } \\
\text { Vinokurova, I. Ju., } \\
\text { Strogalschikova, Z. I. }\end{array}$ \\
\hline $\begin{array}{l}\text { Matvejan } \\
\text { Sel'g }(M s)\end{array}$ & $\begin{array}{l}\text { Матвеева } \\
\text { Сельга }\end{array}$ & $-\ll-$ & $\begin{array}{l}1983 \\
1991\end{array}$ & $\begin{array}{l}\text { Strogalschikova, Z. I., } \\
\text { Vinokurova, I. Ju. }\end{array}$ \\
\hline $\begin{array}{l}\text { Mecantaga } \\
(\mathrm{Mec})\end{array}$ & Залесье & $-\ll-$ & 1983 & Strogalschikova, Z. I. \\
\hline Mägi (Mäg) & $\begin{array}{l}\text { Горнее } \\
\text { Шелтозеро }\end{array}$ & $-\ll-$ & 1991 & Vinokurova, I. Ju. \\
\hline Ogerišt (Oger) & Огеришта & $-\ll-$ & 1983 & Strogalschikova, Z. I. \\
\hline Toižeg $(T \check{z})$ & Другая Река & $-\ll-$ & $\begin{array}{l}1980 \\
1983, \\
1991 \\
\end{array}$ & $\begin{array}{l}\text { Onegina, N. F., } \\
\text { Strogalschikova, Z. I., } \\
\text { Vinokurova, I. Ju. } \\
\end{array}$ \\
\hline Šokš $(S ̌)$ & Шокша & $-\ll-$ & $\begin{array}{l}1964 \\
1983\end{array}$ & $\begin{array}{l}\text { Hämäläinen, M. M., } \\
\text { Onegina, N. F., } \\
\text { Strogalschikova, Z. I., } \\
\text { Vinokurova, I. Ju. }\end{array}$ \\
\hline
\end{tabular}




\begin{tabular}{|l|l|l|l|l|}
\hline $\begin{array}{l}\text { Place name in Veps } \\
\text { and abbreviation }\end{array}$ & $\begin{array}{l}\text { Place name in } \\
\text { Russian }\end{array}$ & $\begin{array}{l}\text { Region/district of } \\
\text { the place where the } \\
\text { recording was made }\end{array}$ & $\begin{array}{l}\text { Year } \\
\text { of the } \\
\text { recording }\end{array}$ & Researcher \\
\hline Šoutarv $(\check{S} t)$ & Шелтозеро & $-\ll-$ & 1952, & Evseev, V. Ja., \\
& & & 1959, \\
& & 1962, & Hämäläinen, M. M., \\
& & 1964, & Zullonen, M. I., \\
& & & 1976, & Zaiceva, M. I., \\
& & 1980, & Zuiceva, N. G., \\
& & & 1981, & \\
& & & 1983, & \\
& & & 1991 & \\
\hline Vehkoja $($ Veh $)$ & Вехручей & - & 1989 & Mullonen, I. I. \\
& & & Strogalschikova, Z. I. \\
\hline
\end{tabular}

Middle Veps dialect Eastern subdialects

\begin{tabular}{|c|c|c|c|c|}
\hline $\begin{array}{l}\text { Place name in Veps } \\
\text { and abbreviation }\end{array}$ & $\begin{array}{l}\text { Place name in } \\
\text { Russian }\end{array}$ & $\begin{array}{l}\text { Region/district of } \\
\text { the place where the } \\
\text { recording was made }\end{array}$ & $\begin{array}{l}\text { Year } \\
\text { of the } \\
\text { recording }\end{array}$ & Researcher \\
\hline Kuja $(K j)$ & Куя & $\begin{array}{l}\text { Vologda } \\
\text { region, } \\
\text { Babayevo } \\
\text { district }\end{array}$ & $\begin{array}{l}1962, \\
1963\end{array}$ & $\begin{array}{l}\text { Mitrofanova, A. A., } \\
\text { Zaiceva, M. I., } \\
\text { Mullonen, M. I., } \\
\text { Zaiceva, N. G. }\end{array}$ \\
\hline$O \check{s} t(\check{S} u \check{s} t)$ & Ошта & $\begin{array}{l}\text { Vologda } \\
\text { region, } \\
\text { Vytegra } \\
\text { district }\end{array}$ & $\begin{array}{l}1962, \\
1970, \\
1974, \\
1975, \\
1976, \\
1987\end{array}$ & $\begin{array}{l}\text { Mitrofanova, A. A., } \\
\text { Zaiceva, M. I., } \\
\text { Mullonen, M. I., } \\
\text { Zaiceva, N. G., } \\
\text { Mullonen, I. I. }\end{array}$ \\
\hline Pondal (Pnd) & Пондала & $\begin{array}{l}\text { Vologda } \\
\text { region, } \\
\text { Babayevo } \\
\text { district }\end{array}$ & $\begin{array}{l}1957, \\
1958, \\
1961, \\
1962, \\
1963, \\
1965, \\
1981, \\
1983\end{array}$ & $\begin{array}{l}\text { Bogdanov, N. I., } \\
\text { Zaiceva, M. I., } \\
\text { Mullonen, M. I., } \\
\text { Mitrofanova, A. A., } \\
\text { Zaiceva, N. G., } \\
\text { Mullonen, I. I., } \\
\text { Vinokurova I. Ju., } \\
\text { Strogalschikova, Z. I., } \\
\text { Onegina, N. F. }\end{array}$ \\
\hline
\end{tabular}




\begin{tabular}{|c|c|c|c|c|}
\hline $\begin{array}{l}\text { Place name in Veps } \\
\text { and abbreviation }\end{array}$ & $\begin{array}{l}\text { Place name in } \\
\text { Russian }\end{array}$ & $\begin{array}{l}\text { Region/district of } \\
\text { the place where the } \\
\text { recording was made }\end{array}$ & \begin{tabular}{|l|} 
Year \\
of the \\
recording \\
\end{tabular} & Researcher \\
\hline Püutkask (Pk) & Пелкаска & $\begin{array}{l}\text { Vologda } \\
\text { region, } \\
\text { Vytegra } \\
\text { district }\end{array}$ & 1962 & Mitrofanova, A. A. \\
\hline Päžar' (Päž) & Пяжозеро & $\begin{array}{l}\text { Vologda } \\
\text { region, } \\
\text { Babayevo } \\
\text { district }\end{array}$ & 1983 & Strogalschikova, Z. I. \\
\hline Särggärr' (Sär) & Сяргозеро & $\begin{array}{l}\text { Vologda } \\
\text { region, } \\
\text { Vytegra } \\
\text { district }\end{array}$ & 1962 & Mitrofanova, A. A. \\
\hline 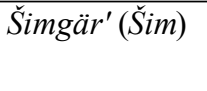 & Шимозеро & $-\ll-$ & $\begin{array}{l}1970 \\
1991^{5}\end{array}$ & $\begin{array}{l}\text { Mullonen, M. I., } \\
\text { Zaiceva, N. G. }\end{array}$ \\
\hline Voilaht $(V l)$ & Войлахта & $\begin{array}{l}\text { Vologda } \\
\text { region, } \\
\text { Babayevo } \\
\text { district }\end{array}$ & $\begin{array}{l}1960, \\
1962, \\
1963, \\
1972, \\
1975, \\
1981, \\
1983\end{array}$ & $\begin{array}{l}\text { Hämäläinen, M. M., } \\
\text { Mitrofanova, A. A., } \\
\text { Mullonen, M. I., } \\
\text { Zaiceva, M., I., } \\
\text { Väizinen, T. I., } \\
\text { Onegina, N. F., } \\
\text { Zaiceva, N. G., } \\
\text { Strogalschikova, Z. I. }\end{array}$ \\
\hline Väräsär $(V \ddot{r} r)$ & Кривозеро & $\begin{array}{l}\text { Vologda } \\
\text { region, } \\
\text { Vytegra } \\
\text { district }\end{array}$ & $\begin{array}{l}1968^{6} \\
1970^{7}\end{array}$ & $\begin{array}{l}\text { Mullonen, M. I., } \\
\text { Zaiceva, M. I. }\end{array}$ \\
\hline
\end{tabular}

5. Recorded in Oshta (Ošt), in Gimreka (Himdeg), in Voznesenye (Voznesenj).

6. Recorded in Nemzha (Nemž).

7. Recorded in Oshta $(O \check{s} t)$. 
Middle Veps dialect Western subdialects

\begin{tabular}{|c|c|c|c|c|}
\hline $\begin{array}{l}\text { Place name in Veps } \\
\text { and abbreviation }\end{array}$ & $\begin{array}{l}\text { Place name in } \\
\text { Russian }\end{array}$ & $\begin{array}{l}\text { Region/district of } \\
\text { the place where the } \\
\text { recording was made }\end{array}$ & $\begin{array}{l}\text { Year } \\
\text { of the } \\
\text { recording }\end{array}$ & Researcher \\
\hline Haragl (Har) & Харагиничи & $\begin{array}{l}\text { Leningrad } \\
\text { region, Tikh- } \\
\text { vin district }\end{array}$ & 1986 & $\begin{array}{l}\text { Zaiceva, N. G., } \\
\text { Mullonen, I. I., } \\
\text { Vinokurova, I. Ju. }\end{array}$ \\
\hline Čikl (Čik) & Чикозеро & $\begin{array}{l}\text { Leningrad } \\
\text { region, Podpo- } \\
\text { rozhye district }\end{array}$ & $\begin{array}{l}1959, \\
1965\end{array}$ & $\begin{array}{l}\text { Hämäläinen, M. M., } \\
\text { Zaiceva, M. I., } \\
\text { Mullonen, M. I. }\end{array}$ \\
\hline Järved (Jä) & Озера & $-\ll-$ & $\begin{array}{l}1961, \\
1980 \\
1983 \\
1985\end{array}$ & \begin{tabular}{|l|} 
Zaiceva, M. I., \\
Mullonen, M. I., \\
Zaiceva, N. G., \\
Mullonen, I. I., \\
Vinokurova, I. Ju., \\
Strogalschikova, Z. I. \\
\end{tabular} \\
\hline Karhil (Kar) & Каргиничи & $-\ll-$ & $\begin{array}{l}1958, \\
1959 \\
\end{array}$ & Hämäläinen, M. M. \\
\hline Korbal (Kor) & Корбиничи & $\begin{array}{l}\text { Leningrad } \\
\text { region, } \\
\text { Tikhvin } \\
\text { district }\end{array}$ & $\begin{array}{l}1962, \\
1986\end{array}$ & $\begin{array}{l}\text { Mitrofanova, A. A., } \\
\text { Zaiceva, N. G., } \\
\text { Mullonen I. I., } \\
\text { Vinokurova, I. Ju. }\end{array}$ \\
\hline Korval (Korv) & Корвала & $-\ll-$ & 1972 & Zaiceva, M. I. \\
\hline Kukkaz $(K k z)$ & Куккас & $\begin{array}{l}\text { Leningrad } \\
\text { region, Lodey- } \\
\text { nopolsky } \\
\text { district } \\
\end{array}$ & $1959^{8}$ & Hämäläinen, M. M. \\
\hline Kurb (Kurb) & Курба & $\begin{array}{l}\text { Leningrad } \\
\text { region, Podpo- } \\
\text { rozhye district } \\
\end{array}$ & 1989 & $\begin{array}{l}\text { Mullonen I. I., } \\
\text { Vinokurova, I. Ju., } \\
\text { Kuznetsova, V. P. }\end{array}$ \\
\hline $\operatorname{Ladv}(\operatorname{Ladv})$ & Ладва & $-\ll-$ & $\begin{array}{l}1961, \\
1968, \\
1980, \\
1981, \\
1983, \\
1989, \\
1991\end{array}$ & $\begin{array}{l}\text { Mullonen M. I., } \\
\text { Zaiceva, M. I., } \\
\text { Onegina, N. F., } \\
\text { Zaiceva, N. G., } \\
\text { Mullonen I. I., } \\
\text { Vinokurova, I. Ju., } \\
\text { Strogalschikova, Z. I., } \\
\text { Kuznetsova, V. P., } \\
\text { Lukina, N. } \\
\end{array}$ \\
\hline
\end{tabular}

8. Recorded in Shapsha ( 


\begin{tabular}{|c|c|c|c|c|}
\hline $\begin{array}{l}\text { Place name in Veps } \\
\text { and abbreviation }\end{array}$ & $\begin{array}{l}\text { Place name in } \\
\text { Russian }\end{array}$ & $\begin{array}{l}\text { Region/district of } \\
\text { the place where the } \\
\text { recording was made }\end{array}$ & $\begin{array}{l}\text { Year } \\
\text { of the } \\
\text { recording }\end{array}$ & Researcher \\
\hline Mäggärr $(M g)$ & Мягозеро & $-\ll-$ & $\begin{array}{l}1980 \\
1983 \\
1985 \\
1991\end{array}$ & $\begin{array}{l}\text { Zaiceva, N. G., } \\
\text { Mullonen I. I., } \\
\text { Vinokurova, I. Ju., } \\
\text { Strogalschikova, Z. I. }\end{array}$ \\
\hline $\mathrm{Nem} \check{z}(\mathrm{Nem})$ & Немжа & $-\ll-$ & $\begin{array}{l}1980 \\
1990\end{array}$ & $\begin{array}{l}\text { Mullonen I. I., } \\
\text { Vinokurova, I. Ju. }\end{array}$ \\
\hline $\operatorname{Nirgl}(\mathrm{Nir})$ & Ниргиничи & $-\ll-$ & 1958 & Hämäläinen, M. M. \\
\hline Noidal (Noid) & Нойдала & $\begin{array}{l}\text { Leningrad } \\
\text { region, Tikh- } \\
\text { vin district }\end{array}$ & 1972 & Zaiceva, M. I. \\
\hline $\operatorname{Norj}($ Nor $)$ & Норгина & $\begin{array}{l}\text { Leningrad } \\
\text { region, Podpo- } \\
\text { rozhye district } \\
\end{array}$ & 1983 & $\begin{array}{l}\text { Mullonen I. I., } \\
\text { Strogalschikova, Z. I. }\end{array}$ \\
\hline Nürgl (Nür) & Нюрговичи & $\begin{array}{l}\text { Leningrad } \\
\text { region, Tikh- } \\
\text { vin district } \\
\end{array}$ & 1986 & $\begin{array}{l}\text { Zaiceva, N. G., } \\
\text { Mullonen I. I., } \\
\text { Vinokurova, I. Ju. }\end{array}$ \\
\hline Pecoil (Pec) & Пелдуши & $\begin{array}{l}\text { Leningrad } \\
\text { region, } \\
\text { Podporozhye } \\
\text { district }\end{array}$ & $\begin{array}{l}1968, \\
1980 \\
1991\end{array}$ & $\begin{array}{l}\text { Zaiceva, M. I., } \\
\text { Mullonen, M. I., } \\
\text { Zaiceva, N. G., } \\
\text { Mullonen I. I., } \\
\text { Vinokurova, I. Ju. }\end{array}$ \\
\hline Pečl' (Peč) & Печеницы & $\begin{array}{l}\text { Leningrad } \\
\text { region, Lodey- } \\
\text { nopolsky } \\
\text { district } \\
\end{array}$ & $\begin{array}{l}1958 \\
1959\end{array}$ & Hämäläinen, M. M. \\
\hline $\operatorname{Rebag}^{\prime}(R e b)$ & $\begin{array}{l}\text { Ребов } \\
\text { Конец }\end{array}$ & $\begin{array}{l}\text { Leningrad } \\
\text { region, Tikh- } \\
\text { vin district }\end{array}$ & 1972 & Zaiceva, M. I. \\
\hline Šondjal (Šon) & Шондовичи & $\begin{array}{l}\text { Leningrad } \\
\text { region, Podpo- } \\
\text { rozhye district } \\
\end{array}$ & $\begin{array}{l}1985 \\
1991\end{array}$ & $\begin{array}{l}\text { Zaiceva, N. G., } \\
\text { Mullonen I. I., } \\
\text { Vinokurova, I. Ju. } \\
\end{array}$ \\
\hline Vil'häl (Vil) & Ярославичи & $-\ll-$ & $\begin{array}{l}1968 \\
1980 \\
1983 \\
1985\end{array}$ & \begin{tabular}{|l} 
Zaiceva, M. I., \\
Mullonen, M. I., \\
Zaiceva, N. G., \\
Mullonen I. I., \\
Vinokurova, I. Ju., \\
Strogalschikova, Z. I.
\end{tabular} \\
\hline
\end{tabular}


Southern Veps dialect

\begin{tabular}{|c|c|c|c|c|}
\hline $\begin{array}{l}\text { Place name in Veps } \\
\text { and abbreviation }\end{array}$ & $\begin{array}{l}\text { Place name in } \\
\text { Russian }\end{array}$ & $\begin{array}{l}\text { Region/district of } \\
\text { the place where the } \\
\text { recording was made }\end{array}$ & $\begin{array}{l}\text { Year } \\
\text { of the } \\
\text { recording }\end{array}$ & Researcher \\
\hline Arskaht' $($ Ars $)$ & Радогощь & $\begin{array}{l}\text { Leningrad } \\
\text { region, } \\
\text { Boksitogorsk } \\
\text { district }\end{array}$ & $\begin{array}{l}1969 \\
1983 \\
2012\end{array}$ & $\begin{array}{l}\text { Zaiceva, M. I., } \\
\text { Mullonen, M. I., } \\
\text { Strogalschikova, Z. I., } \\
\text { Zaiceva, N. G., } \\
\text { Mullonen I. I. }\end{array}$ \\
\hline Bölämägi (Bm) & Белячиха & $-\ll-$ & 1969 & $\begin{array}{l}\text { Zaiceva, M. I., } \\
\text { Mullonen, M. I. }\end{array}$ \\
\hline Bor (Bor) & $\begin{array}{l}\text { Бор (Крас- } \\
\text { ный Бор) }\end{array}$ & $-\ll-$ & $\begin{array}{l}1983, \\
1985\end{array}$ & $\begin{array}{l}\text { Strogalschikova, Z. I., } \\
\text { Vinokurova, I. Ju. }\end{array}$ \\
\hline Čidoi (Čid) & Чидово & $-\ll-$ & 1972 & Zaiceva, M. I. \\
\hline $\begin{array}{l}\text { Fedramägi } \\
(F m)\end{array}$ & $\begin{array}{l}\text { Федорова } \\
\text { Гора }\end{array}$ & $-\ll-$ & 1969 & $\begin{array}{l}\text { Zaiceva, M. I., } \\
\text { Mullonen, M. I. }\end{array}$ \\
\hline Kortlaht $(\mathrm{Krl})$ & Кортлахта & $-\ll-$ & 1966 & $\begin{array}{l}\text { Zaiceva, M. I., } \\
\text { Mullonen, M. I. }\end{array}$ \\
\hline Maigär (Mai) & Боброзеро & $-\ll-$ & $\begin{array}{l}1969, \\
1983\end{array}$ & $\begin{array}{l}\text { Zaiceva, M. I., } \\
\text { Mullonen, M. I., } \\
\text { Vinokurova, I. Ju., } \\
\text { Zaiceva, N. G., } \\
\text { Mullonen I. I., } \\
\text { Strogalschikova, Z. I. }\end{array}$ \\
\hline Laht (Lah) & Лахта & $-\ll-$ & $\begin{array}{l}1958, \\
1985\end{array}$ & $\begin{array}{l}\text { Bogdanov, N. I., } \\
\text { Zaiceva, M. I., } \\
\text { Vinokurova, I. Ju., } \\
\text { Zaiceva, N. G., } \\
\text { Mullonen I. I. }\end{array}$ \\
\hline $\begin{array}{l}\text { Maksimägi } \\
(\mathrm{Mm})\end{array}$ & $\begin{array}{l}\text { Максимова } \\
\text { Гора }\end{array}$ & $-\ll-$ & $\begin{array}{l}1969, \\
1991\end{array}$ & $\begin{array}{l}\text { Zaiceva, M. I., } \\
\text { Mullonen, M. I., } \\
\text { Zaiceva, N. G. }\end{array}$ \\
\hline Požarišš (Pož) & Пожарище & $-\ll-$ & 1966 & $\begin{array}{l}\text { Zaiceva, M. I., } \\
\text { Mullonen, M. I., }\end{array}$ \\
\hline Sodjärv (Sod) & Сидорово & $-\ll-$ & $\begin{array}{l}1958, \\
1964, \\
1983, \\
1985, \\
2012\end{array}$ & $\begin{array}{l}\text { Bogdanov, N. I., } \\
\text { Zaiceva, M. I., } \\
\text { Mullonen, M. I., } \\
\text { Strogalschikova, Z. I., } \\
\text { Zaiceva, N. G., } \\
\text { Mullonen I. I. }\end{array}$ \\
\hline
\end{tabular}




\begin{tabular}{|l|l|l|l|l|}
\hline $\begin{array}{l}\text { Place name in Veps } \\
\text { and abbreviation }\end{array}$ & $\begin{array}{l}\text { Place name in } \\
\text { Russian }\end{array}$ & $\begin{array}{l}\text { Region/district of } \\
\text { the place where the } \\
\text { recording was made }\end{array}$ & $\begin{array}{l}\text { Year } \\
\text { of the } \\
\text { recording }\end{array}$ & Researcher \\
\hline Šidjärv $($ Šid) & Прокушево & $-\ll-$ & $\begin{array}{l}1958, \\
1985\end{array}$ & $\begin{array}{l}\text { Bogdanov, N. I., } \\
\text { Vinokurova, I. Ju., } \\
\text { Zaiceva, N. G., } \\
\text { Mullonen I. I. }\end{array}$ \\
\hline Timoо $($ Tim) & $\begin{array}{l}\text { Саньков } \\
\text { Бор }\end{array}$ & $-\ll-$ & 1983 & $\begin{array}{l}\text { Zaiceva, N. G., } \\
\text { Mullonen I. I. }\end{array}$ \\
\hline $\begin{array}{l}\text { Vaagedjärv } \\
\text { (Vg) }\end{array}$ & Белое озеро & $-\ll-$ & $\begin{array}{l}1966, \\
1983, \\
1985\end{array}$ & $\begin{array}{l}\text { Zaiceva, M. I., } \\
\text { Mullonen, M. I., } \\
\text { Strogalschikova, Z. I., } \\
\text { Zaiceva, N. G., } \\
\text { Mullonen I. I. }\end{array}$ \\
\hline
\end{tabular}

